\title{
ELEMENTAL COMPOSITION OF BLOOD OF INFERTILE PATIENTS PARTICIPATING IN ASSISTED REPRODUCTION PROGRAMS
}

Syrkasheva AG $\bowtie$, Frankevich VE, Dolgushina NV

Kulakov National Medical Research Center for Obstetrics, Gynecology and Perinatology, Moscow, Russia

\begin{abstract}
The association between levels of trace elements, endocrine diseases and reproductive impairments is actively investigated currently. In this connection, it seems relevant to study elemental status (elemental composition of blood and amounts of elements therein) of infertile patients enlisted in programs employing assisted reproductive technologies (ART). This study aimed to analyze trace elements in blood of infertile patients, relationship between the level of such trace elements and parameters of the ART programs they are in. The study included 30 infertile patients aged 18-39 years. Relying on inductively coupled plasma mass spectrometry, we identified concentrations of 31 chemical element in blood of the participants. Two elements out of 31 (antimony and beryllium) were not found in any blood sample; 10 elements (titanium, chromium, cobalt, nickel, arsenic, mercury, barium, gold, vanadium) were detected in some blood samples, the remaining 19 elements were found in all samples. Age of the patients correlated negatively with the level of silicon $(r=-0.384 ; p=0.036)$ and positively with the level of molybdenum $(r=0.384 ; p=0.036)$. The level of anti-mullerian hormone was in a significant negative correlation with the level of lithium $(r=-0.367 ; p=0.046)$. The level of free thyroxine was in a significant negative correlation with the level of boron $(r=-0.402 ; p=0.028)$ and a positively correlated with the levels of iron $(r=0.410 ; p=0.024)$ and silver $(r=0.432 ; p=0.017)$. Considering the embryological cycle, we noted a positive correlation between the level of silicon and the number of blastocysts obtained $(r=0.387 ; p=0.034)$. There was no statistical relationship registered between elemental composition of blood the frequency of pregnancy in ART cycles.
\end{abstract}

Keywords: assisted reproductive technologies, embryos, pregnancy, heavy metals, mass spectrometry, trace elements, blood elemental status, AMH

Author contribution: Syrkasheva AG - conducting the clinical stage of the study, statistical processing of data, article authoring; Frankevich VE — conducting mass spectrometric studies; Dolgushina NV — article authoring, final review.

Compliance with ethical standards: the study was approved by the ethics committee of the V.I. Kulakov National Medical Research Center for Obstetrics, Gynecology and Perinatology (Minutes \#10 of October 20, 2016).

$\triangle$ Correspondence should be addressed: Anastasia G. Syrkasheva Akademika Oparina, 4, Moscow, 117997; a_syrkasheva@oparina4.ru

Received: 10.02.2021 Accepted: 24.02.2021 Published online: 28.02.2021

DOI: $10.24075 /$ brsmu.2021.010

\section{ЭЛЕМЕНТНЫЙ СОСТАВ КРОВИ ПАЦИЕНТОК С БЕСПЛОДИЕМ В ПРОГРАММАХ ВСПОМОГАТЕЛЬНЫХ РЕПРОДУКТИВНЫХ ТЕХНОЛОГИЙ}

А. Г. Сыркашева $凶$, В. Е. Франкевич, Н. В. Долгушина

Национальный медицинский исследовательский центр акушерства, гинекологии и перинатологии имени В. И. Кулакова, Москва, Россия

В связи с активным изучением ассоциаций между уровнями микроэлементов, эндокринными заболеваниями и нарушением репродуктивной функции представляется актуальным изучение элементного статуса у пациенток с бесплодием в программах вспомогательных репродуктивных технологий (ВРТ). Целью работы было проанализировать у пациенток с бесплодием содержание микроэлементов, связь между уровнем микроэлементов в их крови и параметрами программ ВРТ. В исследование включено 30 пациенток с бесплодием в возрасте 18-39 лет. Определяли концентрации 31 химического элемента в крови пациенток методом масс-спектрометрии с индуктивно-связанной плазмой. Два элемента из 31 (сурьма и бериллий) не были обнаружены ни в одном образце крови, 10 элементов (титан, хром, кобальт, никель, мышьяк, ртуть, барий, золото, ванадий) выявлены в части образцов крови, оставшиеся 19 элементов - во всех образцах. Возраст пациенток находился в отрицательной корреляционной связи с уровнем кремния ( $r=-0,384 ; p=0,036)$ и в положительной — с уровнем молибдена $(r=0,384 ; p=0,036)$. Уровень антимюллерова гормона находился в значимой отрицательной корреляционной связи с уровнем лития ( $r=-0,367 ; p=0,046)$. Уровень свободного тироксина находился в значимой отрицательной корреляционной связи с уровнем бора $(r=-0,402 ; p=0,028)$ и положительной корреляционной связи с уровнем железа $(r=0,410 ; p=0,024)$ и серебра $(r=0,432 ; p=0,017)$. При оценке эмбриологического этапа отмечена положительная корреляционная связь между уровнем кремния и числом полученных бластоцист ( $r=0,387 ; p=0,034)$. Не выявлено статистической зависимости между элементным составом крови и частотой наступления беременности в циклах ВРТ.

Ключевые слова: вспомогательные репродуктивные технологии, эмбрионы, беременность, тяжелые металлы, масс-спектрометрия, микроэлементы, әлементный состав крови, АМГ

Вклад авторов: А. Г. Сыркашева - проведение клинического этапа исследования, статистическая обработка данных, написание текста статьи; В. Е. Франкевич - проведение масс-спектрометрических исследований, Н. В. Долгушина - написание текста статьи, финальное рецензирование.

Соблюдение этических стандартов: исследование одобрено этическим комитетом НМИЦ АГП им. В. И. Кулакова (протокол № 10 от 20 октября 2016 г.).

$\checkmark$ Для корреспонденции: Анастасия Григорьевна Сыркашева ул. Академика Опарина, г. Москва, 4117485; a_syrkasheva@oparina4.ru

Статья получена: 10.02.2021 Статья принята к печати: 24.02.2021 Опубликована онлайн: 28.02.2021

DOI: $10.24075 /$ vrgmu.2021.010

The term "trace elements" appeared in the middle of the $20^{\text {th }}$ century. According to the definition from the Medical Encyclopedic Dictionary, trace elements are chemical elements contained in body tissues at the concentrations of 1:100,000 or below. There are essential (necessary) trace elements, which are bioelements vitally important for sustaining life. They are integral components of the human body. There are also conditionally essential trace elements, for which there is a growing body of evidence backing their role in supporting normal functioning of the body. Finally, there are toxic or potentially toxic trace elements, those that the body holds in small amounts only, with their role and possible negative effects not well understood currently [1]. 
The world scientific community has grown interested in trace elements when researchers began investigating specific diseases that have a direct connection with certain elements. The most prominent examples of such diseases are the Minamata disease (mercury poisoning) and Itai-Itai (cadmium poisoning).

Elemental status is also well known to play a role in development of other diseases, as is the case with iron deficiency and anemia, iodine deficiency and thyroid pathology, zinc deficiency and skin diseases and nervous system disorders.

However, this area of medicine remains one of the least studied. Firstly, this is due to the low concentrations of various trace elements in the human body: detecting and quantifying them requires application of complex and expensive methods. Secondly, there are no data on the metabolism of rare trace elements in the body: samples of human blood and/or hair are mainly used to study them. Thirdly, changes in the composition of trace elements are well studied only in the context of specific diseases. Currently, researchers actively develop this area. For example, there are studies aimed at uncovering the relationship between changes in the composition of trace elements and endocrine system diseases [2, 3].

In 1984, the International Society for Trace Element Research in Humans was founded. Its goals are to consolidate and distribute data on the biological role of trace elements in various pathological processes in human beings.

Investigating the role of trace elements in reproductive disorders is a difficult yet rewarding task. Patients participating in programs relying on assisted reproductive technologies (ART) are an interesting group to study. Firstly, they are young women without chronic somatic diseases and with good medical examination results (the examination mandatory before joining an ART program). Secondly, this group allows studying the embryological parameters, such as quality of oocytes and embryos, frequency of oocyte fertilization. Therefore, we decided to select this category of patients for the present study.

This study aimed to analyze the content of trace elements in infertile patients, investigate the relationship between the level of trace elements in their blood and the parameters of ART programs designed for them.

\section{METHODS}

The study included 30 patients who applied for ART infertility treatment 2017 to 2018. The inclusion criteria were: no contraindications for ART; normal karyotype of both spouses; absence of severe male factor (100\% teratozoospermia, absolute asthenozoospermia, all types of azoospermia); age 18 through 39 years; body mass index (BMI) $19-25 \mathrm{~kg} / \mathrm{m}^{2}$. All the participating patients have been residents of Moscow for the last 5 years. The exclusion criteria were: use of donor gametes, surrogacy; obtaining three or less oocytes on the day of transvaginal ovarian puncture.

All the couples included in the study were examined as necessary before enrolling in an ART program [3].

Ovarian stimulation followed the protocol with gonadotropin releasing hormone antagonists [4]. For transvaginal ovarian puncture and oocyte aspiration, we relied on the standard technique [4].

Venous blood was sampled for examination on the day of transvaginal puncture; the samples, once taken, were cryopreserved at $-70{ }^{\circ} \mathrm{C}$. Inductively coupled plasma mass spectrometry enabled quantification of essential and toxic trace elements in the patients' blood. The laboratory that studied the samples had no access to the clinical particulars of the participants. We identified concentrations of the following trace elements: lithium $(\mathrm{Li})$, boron $(\mathrm{B})$, sodium $(\mathrm{Na})$, magnesium $(\mathrm{Mg})$, aluminum (Al), silicon (Si), potassium (K), calcium (Ca), titanium (Ti), chromium (Cr), manganese $(\mathrm{Mn})$, iron $(\mathrm{Fe})$, cobalt (Co), nickel (Ni), copper (Cu), zinc (Zn), arsenic (As), selenium (Se), molybdenum (Mo), cadmium (Cd), antimony (Sb), mercury $(\mathrm{Hg})$, lead $(\mathrm{Pb})$, barium $(\mathrm{Ba})$, gold $(\mathrm{Au})$, vanadium $(\mathrm{V})$, silver $(\mathrm{Ag})$, beryllium $(\mathrm{Be})$, bismuth $(\mathrm{Bi})$, tungsten $(\mathrm{W})$, gallium $(\mathrm{Ga})(31$ elements).

The oocytes were fertilized in vitro, following the "classical" in vitro fertilization (IVF) technique, or through intracytoplasmic sperm injection (ICSI). The embryos were cultivated and transfered using methods accepted in clinical practice [4].

Fourteen days after transfer to the uterine cavity, we measured the concentration of $\beta$-hCG in the patient's blood. In case of registration of the embryo's heartbeat 5 weeks after the transfer, we announced clinical pregnancy.

SPSS 22 (IBM; USA) software package enabled statistical analysis. Normally distributed data were presented as mean (standard deviation). In comparison of category variables, our statistical analysis relied on the $\chi^{2}$ test, in comparison of medians - on the Mann-Whitney test. Abnormally distributed data were presented as median (interquartile range). Pearson criterion was factored into the correlation analysis.

The differences between statistical values were considered significant at $p<0.05$.

\section{RESULTS}

We analyzed concentrations of 31 chemical element in blood of 30 patients. Two elements (antimony and beryllium) were not found in any blood sample; 10 elements (titanium, chromium, cobalt, nickel, arsenic, mercury, barium, gold, vanadium) were detected in some blood samples, the remaining 19 elements were found in all samples. Table 1 presents the chemical elements distribution data.

Age of the patients correlated negatively with the level of silicon ( $r=-0.384 ; p=0.036)$ and positively with the level of molybdenum ( $r=0.384 ; p=0.036$ ). Body weight and $\mathrm{BMI}$ were not connected to the patients' elemental status.

In smoking patients $(n=5)$, the median calcium level was significantly $(p=0.02)$ lower than in non-smokers $(n=25)$ : $98.2 \mathrm{mg} / \mathrm{l}$ versus $102.4 \mathrm{mg} / \mathrm{l}$.

Assessing the obstetric history, we noted that the number of pregnancies positively correlated with the patient's levels of sodium ( $r=0.455 ; p=0.012)$ and chromium $(r=0.484 ; p=0.007)$.

Studying gynecological histories of the patients, we found no connection between the level of trace/macroelements and recorded gynecological diseases (endometriosis, myoma, inflammatory diseases of the pelvic organs), primary or secondary infertility and duration thereof.

Analyzing laboratory indicators of the patients, we discovered a relationship the level of trace elements, antimullerian hormone $(\mathrm{AMH})$ and free thyroxine $\left(\mathrm{T} 4_{\text {free }}\right)$. The level of $\mathrm{AMH}$ was in a significant negative correlation with the level of lithium ( $r=-0.367 ; p=0.046)$. The level of free thyroxine correlated negatively (significant correlation) with the level of boron $(r=-0.402 ; p=0.028)$ and positively with the levels of iron $(r=0.410 ; p=0.024)$ and silver $(r=0.432 ; p=0.017)$ (Table 2).

Evaluation of features of the ovarian stimulation protocol revealed a relationship between the total dose of gonadotropins, the duration of stimulation, the levels of aluminum, zinc, selenium and barium (Table 3).

Analysis of the parameters of oogenesis and early embryogenesis allowed discovering a positive correlation 
Table 1. Concentrations of essential and toxic trace elements in patients

\begin{tabular}{|c|c|c|c|c|}
\hline Element & Detection frequency & Median & Interquartile range & Minimum/maximum \\
\hline Lithium (Li), $\mu \mathrm{g} / \mathrm{l}$ & $100 \%$ & 18.17 & $1.01-34.43$ & $10.22-29.83$ \\
\hline Boron (B), $\mu \mathrm{g} / \mathrm{l}$ & $100 \%$ & 141.6 & $84.0-165.7$ & $68.6-206.5$ \\
\hline Sodium (Na), mg/l & $100 \%$ & 3213.5 & $3070.0-3459.0$ & 2946.0-3567.0 \\
\hline Magnesium (Mg), mg/l & $100 \%$ & 20.0 & $18.8-21.4$ & $13.3-25.9$ \\
\hline Aluminum (Al), $\mu \mathrm{g} / \mathrm{l}$ & $100 \%$ & 60.145 & $51.55-85.03$ & 24.19-126.45 \\
\hline Silicon (Si), $\mu g / l$ & $100 \%$ & 493.200 & $179.9-636.9$ & $38.5-892.1$ \\
\hline Potassium (K), mg/l & $100 \%$ & 165.5 & $152.0-190.0$ & $136.0-210.0$ \\
\hline Calcium (Ca), mg/l & $100 \%$ & 100.550 & $95.2-106.0$ & $92.3-109.5$ \\
\hline Titanium (Ti), $\mu \mathrm{g} / \mathrm{l}$ & $93.3 \%(n=28)$ & 2.745 & $1.88-3.56$ & $0-4.95$ \\
\hline Chromium (Cr), $\mu \mathrm{g} / \mathrm{l}$ & $26.7 \%(n=8)$ & 0 & $0-1.41$ & $0-0.40$ \\
\hline Manganese (Mn), $\mu \mathrm{g} / \mathrm{l}$ & $80.0 \%(n=24)$ & 0.76 & $0.63-0.93$ & $0-1.59$ \\
\hline Iron $(\mathrm{Fe}), \mu \mathrm{g} / \mathrm{l}$ & $100 \%$ & 1377.5 & $965.0-1754.0$ & $401.0-2568.0$ \\
\hline Cobalt (Co), $\mu \mathrm{g} / \mathrm{l}$ & $76.7 \%(n=23)$ & 0.197 & $0.113-0.339$ & $0-0.412$ \\
\hline Nickel (Ni), $\mu \mathrm{g} / \mathrm{l}$ & $36.7 \%(n=11)$ & 0 & $0-0.61$ & $0-6.18$ \\
\hline Copper (Cu), $\mu \mathrm{g} / \mathrm{l}$ & $100 \%$ & 1401.5 & $1121.0-1740.0$ & $788.0-2427.0$ \\
\hline Zinc (Zn), $\mu \mathrm{g} / \mathrm{l}$ & $100 \%$ & 873.0 & $781.0-960.0$ & $593.0-1150.0$ \\
\hline Arsenic (As), $\mu \mathrm{g} / \mathrm{l}$ & $96.7 \%(n=29)$ & 0.41 & $0.23-0.80$ & $0-3.20$ \\
\hline Selenium (Se), $\mu \mathrm{g} / \mathrm{l}$ & $100 \%$ & 85.3 & $76.5-95.6$ & $55.0-119.5$ \\
\hline Molybdenum (Mo), $\mu \mathrm{g} / \mathrm{l}$ & $100 \%$ & 0.705 & $0.640-0.860$ & $0.400-1.150$ \\
\hline Cadmium (Cd), $\mu \mathrm{g} / \mathrm{l}$ & $100 \%$ & 0.275 & $0.20-0.38$ & $0.1-2.42$ \\
\hline Antimony (Sb), $\mu \mathrm{g} / \mathrm{l}$ & 0 & - & - & - \\
\hline Mercury $(\mathrm{Hg}), \mu \mathrm{g} / \mathrm{l}$ & $96.7 \%(n=29)$ & 0.19 & $0.14-0.41$ & $0-0.70$ \\
\hline Lead $(\mathrm{Pb}), \mu \mathrm{g} / \mathrm{l}$ & $100 \%$ & 8.970 & $7.43-12.98$ & $4.80-17.86$ \\
\hline Barium (Ba), $\mu \mathrm{g} / \mathrm{l}$ & $40.0 \%(n=12)$ & 0 & $0-0.55$ & $0-2.28$ \\
\hline Gold (Au), $\mu \mathrm{g} / \mathrm{l}$ & $96.7 \%(n=29)$ & 0.034 & $0.019-0.072$ & $0-0.099$ \\
\hline Vanadium $(\mathrm{V}), \mu \mathrm{g} / \mathrm{l}$ & $3.3 \%(n=1)$ & 0 & $0-0$ & $0-0.278$ \\
\hline Silver (Ag), $\mu \mathrm{g} / \mathrm{l}$ & $100 \%$ & 0.270 & $0.160-0.760$ & $0.030-3.410$ \\
\hline Beryllium (Be), $\mu \mathrm{g} / \mathrm{l}$ & 0 & - & - & - \\
\hline Bismuth (Bi), $\mu \mathrm{g} / \mathrm{l}$ & $100 \%$ & 2.068 & $0.935-2.839$ & $0.107-3.408$ \\
\hline Tungsten (W), $\mu \mathrm{g} / \mathrm{l}$ & $100 \%$ & 0.034 & $0.028-0.045$ & $0.0015-0.050$ \\
\hline Gallium (Ga), $\mu \mathrm{g} / \mathrm{l}$ & $100 \%$ & 0.007 & $0.005-0.009$ & $0.001-0.010$ \\
\hline
\end{tabular}

between the number of blastocysts obtained and the level of silicon ( $r=0.387 ; p=0.034)$. No other significant differences between levels of trace elements and parameters of oogenesis/ early embryogenesis were detected.

Clinical pregnancy was registered in 15 cases (50\%). The level of trace elements did not differ significantly in patients with different ART program outcomes $(p>0.05)$.

\section{DISCUSSION}

The number of studies demonstrating relationship between a person's elemental status and peculiarities of various diseases in this person has been growing in the recent years $[2,5,6]$. In a healthy body, homeostatic mechanisms keep the levels of trace elements within physiological range. However, against the background of changing external conditions (as a rule changes in diet and the surrounding environment, ecology), the balance of trace elements may be broken, which leads to a deficiency or, conversely, an excess of certain substances [3]. Such conditions are difficult to diagnose, mainly due to the lack of a characteristic clinical picture associated with them and problematic access to laboratories capable of analyzing elemental composition of the human body. The discussion about the ideal matrix for trace element analysis (blood/urine/hair) is ongoing [1, 7]. It should also be remembered that it is still unclear what roles many of the trace elements play in the human body, same as the processes of metabolism of trace elements. Elemental status of a person may depend on sex, age and other less obvious attributes [8]. All these factors make research in this area extremely promising.

In this study, we evaluated elemental status of blood of infertile patients who applied for ART programs. One of the inclusion criteria required residency in a region of Russia favorable from the point of view of the trace element balance [9]. Selection of patients with certain clinical characteristics reduces the likelihood of influence of known factors (obesity, endocrine diseases, ecologically unfavorable region of residence) on the elemental status.

The study revealed a relationship between elemental composition of the patients' blood and their clinical characteristics, but uncovered no connection between the women's elemental status and ART program outcomes.

Age of the patients was negatively associated with the level of silicon, while correlating positively with the level of molybdenum. Molybdenum is an essential trace element; silicon can be called an element "probably necessary" for functioning of a human body. Silicon is concentrated in connective tissue: arterial walls, tendons, skin. It is assumed that the content of silicon 
Table 2. Correlation between hormonal parameters and elemental composition of the patients' blood

\begin{tabular}{|c|c|c|c|c|c|c|}
\hline & AMH & $T 4_{\text {free }}$ & Lithium & Boron & Iron & Silver \\
\hline \multirow{2}{*}{$\mathrm{AMH}$} & \multirow{2}{*}{1} & $r=0.130$ & $r=-0.367$ & $r=-0.055$ & $r=0.040$ & $r=0.253$ \\
\hline & & $h=0.495$ & $p=0.046$ & $p=0.773$ & $p=0.835$ & $p=0.177$ \\
\hline \multirow{2}{*}{$\mathrm{T}_{\text {free }}$} & $r=0.130$ & \multirow{2}{*}{1} & $r=0.183$ & $r=-0.402$ & $r=0.410$ & $r=0.432$ \\
\hline & $h=0.495$ & & $p=0.334$ & $p=0.028$ & $p=0.024$ & $p=0.017$ \\
\hline \multirow{2}{*}{ Lithium } & $r=-0.367$ & $r=0.183$ & \multirow{2}{*}{1} & $r=0.104$ & $r=0.258$ & $r=-0.281$ \\
\hline & $p=0.046$ & $p=0.334$ & & $p=0.583$ & $p=0.168$ & $p=0.133$ \\
\hline \multirow{2}{*}{ Boron } & $r=-0.055$ & $r=-0.402$ & $r=0.104$ & \multirow{2}{*}{1} & $r=-0.074$ & $r=-0.329$ \\
\hline & $p=0.773$ & $p=0.028$ & $p=0.583$ & & $p=0.698$ & $p=0.076$ \\
\hline \multirow{2}{*}{ Iron } & $r=0.040$ & $r=0.410$ & $r=0.258$ & $r=-0.074$ & \multirow{2}{*}{1} & $r=-0.59$ \\
\hline & $p=0.835$ & $p=0.024$ & $p=0.168$ & $p=0.698$ & & $p=0.758$ \\
\hline \multirow{2}{*}{ Silver } & $r=0.253$ & $r=0.432$ & $r=-0.281$ & $r=-0.329$ & $r=-0.59$ & \multirow{2}{*}{1} \\
\hline & $p=0.177$ & $p=0.017$ & $p=0.133$ & $p=0.076$ & $p=0.758$ & \\
\hline
\end{tabular}

in the human body changes with age, but the mechanisms behind this change have not been described exhaustively [10]. Molybdenum plays a controversial role in the human body. It is a component of various enzymes. Molybdenum preparations are traditionally used to treat Wilson's disease; in addition, there are reported cases when it was used successfully to treat Crohn's disease [11]. Researchers have shown angiogenesis suppressing properties of molybdenum preparations in the context of pre-clinical anticancer drug studies [12]. At the same time, at elevated concentrations, this metal is toxic. High level of molybdenum in the blood translates into higher risk of arterial hypertension and other cardiovascular diseases [13]. Further research is needed to assess the negative effects of molybdenum on human health.

Osteoporosis and osteopenia are the background conditions for studies analyzing the effect of smoking on calcium metabolism [14]. In our study, smoking patients had reduced calcium levels compared with nonsmokers. Calcium is an important element for a human body; during pregnancy and lactation, the need for this element increases significantly. The data obtained can be used in counseling patients, recommending smoking cessation during pregnancy planning.

The analysis of laboratory indicators showed a negative correlation between levels of lithium and $\mathrm{AMH}$. $\mathrm{AMH}$ is most widely used descriptor of ovarian reserve. Lithium preparations have long been used to treat psychiatric conditions (mainly manic depressive disorders). In some cases, it is necessary to continue taking lithium preparations during pregnancy, which is why researchers pay special attention to evaluation of their negative impact on the reproductive and endocrine systems [15]. A group of Iranian researchers demonstrated a decrease in the expression of genes for steroidogenesis in rat ovaries [16]. The connection between lithium and human ovarian reserve values requires further study.

The level of free thyroxine is connected with the levels of iron, boron and silver. At the same time, there was no connection registered between the levels of thyroid-stimulating hormone and trace elements. Various authors have reported negative relationship between boron and the level of thyroid hormones in animals [17, 18]. In laboratory animals, boron preparations were associated with development of hypothyroidism. Boron regulates the activity of parathyroid hormone, which may explain the link between boron and trace element levels.

Analyzing the ovarian stimulation protocol, we discovered a connection between the levels of aluminum and zinc and the total dose of gonadotropins, as well as a relationship between selenium, barium and the duration of ovarian stimulation. No other studies published report such correlations. Overall, the number of days of stimulation correlates with the duration of the patient cycle's follicular phase, which, in turn, is associated with the ovarian reserve. Duration of the cycle may be influenced by the increased levels of selenium, which is a coenzyme of glutathione peroxidase, an antioxidant enzyme. At the same time, growing level of selenium may be a compensatory response to the increasing concentration of barium, a toxic heavy metal, since selenium plays a key role in detoxification of heavy metals.

Table 3. Features of the superovulation stimulation protocol and elemental composition of the patients' blood

\begin{tabular}{|c|c|c|c|c|c|c|}
\hline & $\begin{array}{c}\text { Number of days of } \\
\text { stimulation }\end{array}$ & $\begin{array}{l}\text { Total dose of } \\
\text { gonadotropins }\end{array}$ & Aluminum & Zinc & Selenium & Barium \\
\hline \multirow{2}{*}{$\begin{array}{l}\text { Number of days of } \\
\text { stimulation }\end{array}$} & \multirow{2}{*}{1} & $r=0.318$ & $r=0.209$ & $r=0.296$ & $r=0.409$ & $r=0.562$ \\
\hline & & $p=0.087$ & $p=0.268$ & $p=0.113$ & $p=0.025$ & $p=0.001$ \\
\hline \multirow{2}{*}{$\begin{array}{l}\text { Total dose of } \\
\text { gonadotropins }\end{array}$} & $r=0.318$ & \multirow{2}{*}{1} & $r=0.588$ & $r=0.469$ & $r=0.246$ & $r=0.029$ \\
\hline & $p=0.087$ & & $p=0.001$ & $p=0.009$ & $p=0.190$ & $p=0.881$ \\
\hline \multirow{2}{*}{ Aluminum } & $r=0.209$ & $r=0.562$ & \multirow{2}{*}{1} & $r=0.354$ & $r=0.006$ & $r=-0.153$ \\
\hline & $p=0.268$ & $p=0.001$ & & $p=0.055$ & $p=0.977$ & $p=0.420$ \\
\hline \multirow{2}{*}{ Zinc } & $r=0.296$ & $r=0.469$ & $r=0.354$ & \multirow{2}{*}{1} & $r=0.351$ & $r=0.175$ \\
\hline & $p=0.113$ & $p=0.009$ & $p=0.055$ & & $p=0.057$ & $p=0.355$ \\
\hline \multirow{2}{*}{ Selenium } & $r=0.409$ & $r=0.246$ & $r=0.006$ & $r=0.351$ & \multirow{2}{*}{1} & $r=0.492$ \\
\hline & $p=0.025$ & $p=0.190$ & $p=0.977$ & $p=0.057$ & & $p=0.006$ \\
\hline \multirow{2}{*}{ Barium } & $r=0.562$ & $r=0.029$ & $r=-0.153$ & $r=0.175$ & $r=0.492$ & \multirow{2}{*}{1} \\
\hline & $p=0.001$ & $p=0.881$ & $p=0.420$ & $p=0.355$ & $p=0.006$ & \\
\hline
\end{tabular}


We have identified a positive link between total gonadotropin dose and zinc and aluminum levels, with a weak positive association between these elements. Zinc is a component of at least 200 different enzymes, and perhaps some of them play a role in the synthesis of steroid hormones and their receptors. The toxic effect aluminum has on oogenesis in rodents was demonstrated by biologists from Brazil. They assume aluminum directly damages ovarian tissues and inhibits antioxidant enzymes [19].

Considering the embryological cycle, we noted a positive correlation between the level of silicon and the number of blastocysts obtained, while the relationship between silicon and the number of oocytes was not registered. Silicon is necessary for formation of bone and connective tissue, but its role in the processes of embryogenesis is currently unknown.

\section{CONCLUSIONS}

We have studied elemental status of infertile patients in ART programs. Most of the trace elements have detectable concentrations in the blood of the patients. We revealed a link between the content of trace elements and patient's age, laboratory indicators (AMH and $\mathrm{T} 4_{\text {free }}$ levels), ovarian stimulation cycle parameters. The effect elemental status of patients has on the outcomes (efficacy) of ART programs requires further research.

\section{References}

1. Skalnyj AV, Rudakov IA. Biojelementologija - novyj termin ili novoe nauchnoe napravlenie? Vestnik OGU. 2005; 2: 4-8. Russian.

2. Talebi S, Ghaedi E, Sadeghi E, Mohammadi H, Hadi A, Clark CCT, et al. Trace Element Status and Hypothyroidism: A Systematic Review and Meta-analysis. Biol Trace Elem Res. 2020; 197 (1): 1-14.

3. Sanjeevi N, Freeland-Graves J, Beretvas SN, Sachdev PK. Trace element status in type 2 diabetes: A meta-analysis. J Clin Diagn Res. 2018; 12 (5): OE01-8.

4. Syrkasheva AG, Dolgushina NV, Makarova NP, Kovalskaya EV, Agarsheva MA. Ishody programm vspomogatel'nyh reproduktivnyh tehnologij u pacientok s dismorfizmami oocitov. Akusherstvo ginekologija. 2015; 7: 56-62. Russian.

5. Sağlam HS, Altundağ H, Atik YT, Dündar MŞ, Adsan Ö. Trace elements levels in the serum, urine, and semen of patients with infertility. Turkish J Med Sci. 2015; 45 (2): 443-8.

6. Zemrani B, Bines JE. Recent insights into trace element deficiencies: causes, recognition and correction. Curr Opin Gastroenterol. 2020; 36 (2): 110-7.

7. Takeuchi H, Taki Y, Nouchi R, Yokoyama R, Kotozaki Y, Nakagawa S, et al. Association of iron levels in hair with brain structures and functions in young adults. J trace Elem Med Biol Organ Soc Miner Trace Elem. 2020; 58: 126436.

8. Laue HE, Moroishi Y, Jackson BP, Palys TJ, Madan JC, Karagas MR Nutrient-toxic element mixtures and the early postnatal gut microbiome in a United States longitudinal birth cohort. Environ Int. 2020; 138: 105613.

9. Skalnyj AV, Kiselev MF, redaktory. Jelementnyj status naselenija Rossii. SPb.: Medkniga «JeLBI-SPb», 2014; 544 s. Russian.

10. Vapirov V, Feoktistov VM, Venskovich AA, Vapirova NV. K voprosu o povedenii kremnija v prirode i ego biologicheskoj roli. Uchenye zapiski Petrozavodskogo gosudarstvennogo universiteta 2017; 2 (163): 95-102. Russian.

\section{Литература}

1. Скальный А. В., Рудаков И. А. Биоэлементология - новый термин или новое научное направление? Вестник ОГУ. 2005 2: 4-8.

2. Talebi S, Ghaedi E, Sadeghi E, Mohammadi H, Hadi A, Clark CCT, et al. Trace Element Status and Hypothyroidism: A Systematic Review and Meta-analysis. Biol Trace Elem Res. 2020; 197 (1): $1-14$.

3. Sanjeevi N, Freeland-Graves J, Beretvas SN, Sachdev PK. Trace element status in type 2 diabetes: A meta-analysis. J Clin Diagn Res. 2018; 12 (5): OE01-8.

4. Сыркашева А. Г., Долгушина Н. В., Макарова Н. П., Ковальская Е. В., Агаршева М. А. Исходы программ вспомогательных репродуктивных технологий у пациенток с дисморфизмами ооцитов. Акушерство и гинекология. 2015; 7: 56-62.

5. Sağlam HS, Altundağ H, Atik YT, Dündar MŞ, Adsan Ö. Trace
11. Novotny JA, Peterson CA. Molybdenum. Adv Nutr. 2018; 9 (3): 272-3.

12. Llamas A, Chamizo-Ampudia A, Tejada-Jimenez M, Galvan A, Fernandez E. The molybdenum cofactor enzyme mARC: Moonlighting or promiscuous enzyme? Biofactors. 2017; 43 (4): 486-94.

13. Shiue I. Higher urinary heavy metal, phthalate, and arsenic but not parabens concentrations in people with high blood pressure, U.S. NHANES, 2011-2012. Int J Environ Res Public Health. 2014; 11 (6): 5989-99.

14. Breitling LP. Smoking as an effect modifier of the association of calcium intake with bone mineral density. J Clin Endocrinol Metab. 2015; 100 (2): 626-35.

15. Neri C, De Luca C, D'oria L, Licameli A, Nucci M, Pellegrino M, et al. Managing fertile women under lithium treatment: the challenge of a Teratology Information Service. Minerva Ginecol. 2018; 70 (3): 261-7.

16. Mirakhori F, Zeynali B, Tafreshi AP, Shirmohammadian A. Lithium

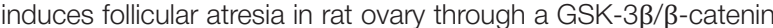
dependent mechanism. Mol Reprod Dev. 2013; 80 (4): 286-96.

17. Luca E, Fici L, Ronchi A, Marandino F, Rossi ED, Caristo ME, et al. Intake of Boron, Cadmium, and Molybdenum enhances rat thyroid cell transformation. J Exp Clin Cancer Res. 2017; 36 (1): 73.

18. Popova EV, Tinkov AA, Ajsuvakova OP, Skalnaya MG, Skalny AV. Boron - A potential goiterogen? Med Hypotheses. 2017; 104: 63-7.

19. da Silva Lima D, da Silva Gomes L, de Sousa Figueredo E, de Godoi MM, Silva EM, da Silva Neri HF, et al. Aluminum exposure promotes histopathological and pro-oxidant damage to the prostate and gonads of male and female adult gerbils. Exp Mol Pathol. 2020; 116: 104486.

elements levels in the serum, urine, and semen of patients with infertility. Turkish J Med Sci. 2015; 45 (2): 443-8.

6. Zemrani B, Bines JE. Recent insights into trace element deficiencies: causes, recognition and correction. Curr Opin Gastroenterol. 2020; 36 (2): 110-7.

7. Takeuchi H, Taki Y, Nouchi R, Yokoyama R, Kotozaki Y, Nakagawa S, et al. Association of iron levels in hair with brain structures and functions in young adults. J trace Elem Med Biol Organ Soc Miner Trace Elem. 2020; 58: 126436.

8. Laue HE, Moroishi Y, Jackson BP, Palys TJ, Madan JC, Karagas MR. Nutrient-toxic element mixtures and the early postnatal gut microbiome in a United States longitudinal birth cohort. Environ Int. 2020; 138: 105613.

9. Скальный А. В., Киселев М. Ф., редакторы. Элементный статус населения России. СПб.: Медкнига «ЭЛБИ-СПб», 2014; 544 c. 
10. Вапиров В. В., Феоктистов В. М., Венскович А. А., Вапирова Н. В. К вопросу о поведении кремния в природе и его биологической роли. Ученые записки Петрозаводского государственного университета. 2017; 2 (163): 95-102.

11. Novotny JA, Peterson CA. Molybdenum. Adv Nutr. 2018; 9 (3): 272-3.

12. Llamas A, Chamizo-Ampudia A, Tejada-Jimenez M, Galvan A, Fernandez E. The molybdenum cofactor enzyme mARC: Moonlighting or promiscuous enzyme? Biofactors. 2017; 43 (4): 486-94.

13. Shiue I. Higher urinary heavy metal, phthalate, and arsenic but not parabens concentrations in people with high blood pressure, U.S. NHANES, 2011-2012. Int J Environ Res Public Health. 2014; 11 (6): 5989-99.

14. Breitling LP. Smoking as an effect modifier of the association of calcium intake with bone mineral density. J Clin Endocrinol Metab. 2015; 100 (2): 626-35.

15. Neri C, De Luca C, D'oria L, Licameli A, Nucci M, Pellegrino M, et al. Managing fertile women under lithium treatment: the challenge of a Teratology Information Service. Minerva Ginecol. 2018; 70 (3): 261-7.

16. Mirakhori F, Zeynali B, Tafreshi AP, Shirmohammadian A. Lithium induces follicular atresia in rat ovary through a GSK-3 $\beta / \beta$-catenin dependent mechanism. Mol Reprod Dev. 2013; 80 (4): 286-96.

17. Luca E, Fici L, Ronchi A, Marandino F, Rossi ED, Caristo ME, et al. Intake of Boron, Cadmium, and Molybdenum enhances rat thyroid cell transformation. J Exp Clin Cancer Res. 2017; 36 (1): 73.

18. Popova EV, Tinkov AA, Ajsuvakova OP, Skalnaya MG, Skalny AV. Boron - A potential goiterogen? Med Hypotheses. 2017; 104: 63-7.

19. da Silva Lima D, da Silva Gomes L, de Sousa Figueredo E, de Godoi MM, Silva EM, da Silva Neri HF, et al. Aluminum exposure promotes histopathological and pro-oxidant damage to the prostate and gonads of male and female adult gerbils. Exp Mol Pathol. 2020; 116: 104486. 